\title{
Sejarah Dakwah Nabi Muhammad pada Mayarakat Madinah: Analisis Model Dakwah Ukhuwah Basyariah dan Ukhuwah Wathaniyah
}

\author{
Azhar \\ Dosen Fakultas Dakwah dan Komunikasi UIN Sumatera Utara \\ azharsitompul8@gmail.com
}

\begin{abstract}
In the course of the missionary history which has been exemplified by the Prophet Muhammad, especially in Medina, propaganda of prophets made significant progress. Especially after the passing of Piagam Madinah. The success of propagation of prophets in Medina can not be separated from the use of models of propaganda by the Prophet Muhammad. There are some interesting da'wah models for further analysis. The model of dakwah in question is the model of dakwah Ukhuwah Wathaniyah and Ukhuwah Basyariah. As for Ukhuwah Wathaniyah is one of the dakwah method that was propagated by Prophet Muhammad saw in order to live a sense of love and belonging to the state, which in this case is Medina. While Ukhuwah Basyariah is a method of propagation which is intensified by the Prophet Muhammad in order to foster the spirit of brotherhood on the basis of humanity. In the propagation model Ukhuwah Wathaniyah proclaimed by the prophet, the planting of love and owning the homeland becomes a very important thing. It was built with expeditions and military training to hone the power to protect the brother and the motherland. The Ukhuwah Basyariah is built by instilling the importance of the value of human equality before Allah Swt, although humans come from different ethnic, cultural, traditions, and religions. Thus, this model will make Muslims more tolerant to non. Islam
\end{abstract}

Key words: Dakwah, Ukhuwah Wathaniyah, Ukhuwah Basyariah

\begin{abstract}
Abstrak
Dalam perjalanan sejarah dakwah yang telah dicontohkan oleh Nabi Muhammad saw, khususnya di Madinah, dakwah nabi mengalami kemajuan yang signifikan. Terlebih pasca disahkannya Piagama Madinah. Keberhasilan dakwah nabi di Madinah tidak terlepas dari penggunaan model-model dakwah oleh Nabi Muhammad saw. Ada beberapa model dakwah yang menarik untuk dianalisa lebih lanjut. Adapun model dakwah yang dimaksud adalah model dakwah Ukhuwah Wathaniyah dan Ukhuwah Basyariah. Adapun Ukhuwah Wathaniyah merupakan salah satu metode dakwah yang digencarkan oleh Nabi Muhammad saw dalam rangka menghidupkan rasa cinta dan memiliki terhadap Negara, yang dalam hal ini adalah Madinah. Sedangkan Ukhuwah Basyariah adalah metode dakwah yang digencarkan oleh Nabi Muhammad saw dalam rangka menumbuhkan semangat persaudaraan atas dasar kemanusiaan. Dalam model dakwah Ukhuwah Wathaniyah yang dicanangkan oleh nabi, penanaman akan rasa cinta dan memiliki tanah air menjadi hal yang sangat penting. Hal tersebut dibangun dengan melakukan ekspedisi dan latihan militer guna mengasah kekuatan untuk melindungi saudara semuslim dan tanah air. Adapun
\end{abstract}


Ukhuwah Basyariah dibangun dengan menanamkan arti penting nilai kesamaan manusia di hadapan Allah Swt, meskipun manusia berasal dari etnis, budaya, tradisi, dan agama yang berbeda. Dengan demikian, model ini akan menjadikan umat Islam lebih bersikap toleransi terhadap non. Islam.

Kata kunci : Dakwah, Ukhuwah Wathaniyah, Ukhuwah Basyariah

\section{PENDAHULUAN}

Pada dasarnya, pelaksanaan dakwah yang bersifat spesifik, terencana, sistematis, dan strategis yang telah dicontohkan oleh Nabi Muhammad saw merupakan kerangka acuan dakwah yang sebenarnya. Secara historis, para sarjanawan membagi dakwah yang telah dilakukan oleh Nabi Muhammad saw ke dalam dua periode, yaitu periode Makkah yang biasa disebut dengan addaur al-Makki dan periode Madinah yang biasa disebut dengan addaur al-Madani. ${ }^{1}$

Adanya periodesasi dakwah yang telah dicontohkan oleh Nabi Muhammad saw ini merupakan pembuktian bahwa kegiatan dakwah harus senantiasa bergerak, dinamis, serta sesuai dengan kondisi masyarakat. Dengan kata lain, dakwah tidak harus berhenti pada satu masa dan tempat yang sama. Selain itu, kedudukan Nabi Muhammad saw sebagai rahmatan lil 'alamin juga mengharuskan ia untuk berdakwah tidak hanya di Makkah saja, melainkan di tempat lain, termasuk Madinah. Adanya kegiatan dakwah yang sampai ke Madinah tersebut membuktikan bahwa Islam telah meluaskan pengaruhnya, bahkan hingga ke Madinah.

Pada periode addaur al-Makki, aktivitas dakwah Nabi Muhammad saw dibagi menjadi tiga tahap. Tahap pertama, selama tiga tahun disebut dengan dakwah secara sembunyi-sembunyi. Materi dakwah yang disampaikan pada tahap ini merupakan landasan Islam, seperti aqidah dan akhlak. Adapun sasaran dakwahnya adalah kalangan keluarga dan orang-orang terdekatnya,

${ }^{1}$ Terkait awal mula periodesasi dakwah Rasulallah, J. Suyuthi Pulungan berpendapat bahwa awal mula addaur al-Makki dimulai sejak Rasulallah menerima wahyu pertamanya, yaitu surat al-'Alaq ayat 1-5 dan berakhir ketika Rasulallah melakukan hijrah ke Madinah. Adapun addaur al-Madani dimulai sejak tahun $622 \mathrm{M}$, yang merupakan tahun pertama Rasulallah melakukan hijrah dari Makkah ke Madinah, dan berakhir pada tahun $632 \mathrm{M}$ ketika Rasulallah wafat, tepatnya beberapa bulan pasca turunnya wahyu terakhir -ayat ke-3 surat al-Maidah- ketika ia melakukan haji wada' (haji perpisahan). Lihat Shafiyur Rahman Al-Mubarakfury, Sirah Rasul Saw al-Rahiqul Makhtum, Dar al-Khair, Beirut Cet. II, 1998, hlm. 73 dan J. Suyuthi Pulungan, PrinsipPrinsip Pemerintahan Dalam Piagam Madinah Ditinjau Dari Pandangan al-Qur'an, Rajawali Pers, Jakarta, 1994, hlm.1. 
yang kemudian disebut dengan As-Sabiqun Al-Awwalun ${ }^{2}$. Tahap kedua merupakan tahap dakwah secara terang-terangan yang mulai dilakukan pada tahun keempat hingga akhir tahun kesepuluh. Pada tahap ini, ia mengundang beberapa kabilah yang ada di Makkah untuk mendengarkan dakwahnya. Selain itu, ia juga mendapat perlindungan dari Abu Thalib ketika menyampaikan dakwahnya di Bukit Safa. Hal tersebut dilakukan berdasarkan perintah Allah dalam surat As-Syu'ara ayat 2143. Tahap terakhir merupakan tahapan ketika Nabi Muhammad saw mulai melakukan dakwahnya keluar kota Mekkah yang dimulai pada tahun kesepuluh kenabiannya hingga ia hijrah ke Madinah. ${ }^{4}$

Setelah berdakwah di Makkah selama 13 tahun, Nabi Muhammad saw kemudian melanjutkan periode dakwah keduanya, yaitu periode Madinah. Periode dakwah yang berlangsung selama 10 tahun ini, mengalami keberhasilan jika dibandingkan dengan periode sebelumnya. Meskipun pada saat itu suku 'Aus dan Khazraj yang merupakan dua suku asli Madinah sedang mengalami pertikaian. ${ }^{5}$ Selain itu, pada periode addaur al-Madani ini, Nabi Muhammad saw menghadapi masyarakat yang heterogen, baik dari segi keyakinan ${ }^{6}$, etnis, agama, dan bangsa. Keadaan

${ }^{2}$ As-Sabiqun Al-Awwalun merupakan orang-orang yang baru masuk Islam. Adapun yang termasuk ke dalam As-Sabiqun Al-Awwalun yaitu Siti Khadijah yang merupakan istri nabi, Ali bin Abi Thalib yang merupakan saudara sepupu nabi yang baru berusia sepuluh tahun, dan Zaid bin Haritsah. Zaid bin Haritsah pada awalnya adalah tawanan yang dijadikan Khadijah sebagai budak. Kemudian Khadijah menyerahkan Zaid kepada Rasul Saw. Bapak dan pamannya pernah datang menjemput Zaid, akan tetapi Zaid memilih tinggal bersama Rasul Saw, sehingga Rasul Saw mengangkatnya sebagai anak kandungnya sendiri. Sehingga ia disebut Zaid bin Muhammad. Hal ini berakhir setelah Islam membatalkan status. Lihat J. Suyuthi Pulungan, Prinsip-Prinsip Pemerintahan Dalam Piagam Madinah Ditinjau Dari Pandangan alQur'an, hlm. 73-75.

3Artinya: " dan berilah peringatan kepada kerabat-kerabatmu yang terdekat".

4J. Suyuthi Pulungan, Prinsip-Prinsip Pemerintahan Dalam Piagam Madinah Ditinjau Dari Pandangan al-Qur'an, hlm. 73-75.

${ }^{5}$ Suku Aus dan Khazraj adalah suku berkebangsaan Arab dari sebelah Selatan. Selanjutnya lihat Philip K. Hitti, History of The Arabs, Mac Millan Press Ltd, London, 1970, hlm. 31. Lihat juga Bernard Lewis, The Arabs in History, (Terj.) Drs. Said Jamhuri, BangsaBangsa Arab Dalam Lintasan Sejarah, Pedoman Ilmu Jaya, Jakarta, 1988, hlm. 3. Mengenai suku - suku yang ada di Madinah W. Montogomery Watt, menjelaskan bahwa ada delapan suku asli yang menduduki Madinah yakni : Bani Auf, Bani al-Harits, Bani Saidah, Bani Jusyam, Bani Nadzar, Bani Amr Bin Auf, Bani Tsa'labat, dan Bani Aws. W. Montogomery Watt, Muhammad And Statetmen, Oxford University, London, 1979, hlm. 85

${ }^{6}$ Berbeda dengan masyarakat Makkah yang hanya memiliki satu keyakinan, yaitu penyembah berhala (pagan), masyarakat Madinah, khususnya bangsa Arab telah memeluk dan meyakini beraneka ragam agama dan kepercayaan. Sebahagian mereka beragama tauhid, Nasrani, dan ada pula yang menyembah berhala yang berpusat di kota Makkah. Lihat Ali Mushtofa al Ghurraby, Tarikh al Firaq al Islamiyah Wa Nasy'atu al 'ilm al Kalam 'Inda al Muslimin, Maktabah Wa Matba'ah, Al Azhar, Kairo, hlm. 8 
demikian pulalah yang mengakibatkan sering terjadinya konflik di kalangan masyarakat Madinah. Selain itu, adanya campur tangan pihak Yahudi juga menjadi pemicu tingginya tingkat terjadinya konflik di kalangan masyarakat Madinah.

Banyak faktor yang menjadi pemicu keberhasilan dakwah Nabi Muhammad saw dalam periode ini, salah satunya adalah kemampuan Nabi Muhammad saw dalam mengakomodir seluruh potensi dari berbagai suku dan agama yang ada di Madinah. Selain itu, kepiawaiannya dalam menggunakan strategi ukhuwah Islamiyah, ukhuwah Wathoniyah, dan ukhuwah Basyariyah kepada masyarakat muslim juga menjadi faktor penting keberhasilan dakwah Nabi Muhammad saw pada periode ini. Adapun kepada masyarakat non muslim, ia menggunakan strategi adopsi, akomodasi dan seleksi.

Demi melanggengkan usaha dakwahnya, Nabi Muhammad saw membangun sebuah masjid yang tidak hanya digunakan sebagai media beribadah saja, melainkan juga digunakan sebagai pusat penyelenggaraan kegiatan-kegiatan sosial-keagamaan, seperti bermusyawarah, serta menyelesaikan perkara-perkara yang terjadi di masyarakat.7 Selain itu, masjid tersebut juga digunakan untuk menanamkan nilai-nilai persaudaraan dan cinta tanah air, yang juga dimaksudkan untuk menyatukan dan meredakan konflik yang terjadi antara kaun Muhajirin dan Anshor. ${ }^{8}$

Secara sosiologi, keadaan masyarakat Madinah yang heterogen dan plural sangat memerlukan adanya sebuah persatuan dan kesatuan. Konflik-konflik yang terjadi sering kali dipicu oleh ke-heterogenan dan ke-pluralitasan yang ada. ${ }^{9}$ Dalam kajian dakwah, adanya upaya penyatuan di tengah-tengah masyarakat yang heterogen dan plural ini akan lebih memungkinkan misi dakwah Nabi Muhammad saw menjadi fleksibel, berkelanjutan (continueable), dan dapat berfungsi sebagai kekuatan sosial (social force).

Sifat dakwah seperti ini akan menghilangkan praduga yang menyatakan bahwa dakwah Islam tidak dapat merekonstruksi (unrekonstructionable) tatanan yang sudah ada. Sebaliknya, dari sifat inilah akan lahir sebuah pesan dakwah yang indefendent dan efektif. Bentuk nyata yang lebih konkrit dan meluas dari hal tersebut adalah dengan

${ }^{7}$ Muhammad Husein Haykal, The Life of Muhammad, Cresent Publishing, New Delhi, 1976, hlm. 174 - 175.

8 Badri Yatim, Sejarah Peradaban Islam, PT. Raja Grafindo Persada, Jakarta, 200, hlm. 25.

9 Kondisi masyarakat yang majemuk memerlukan sebuah penataan dan pengendalian sosial secara bijak, agar tercipta rasa aman, damai dan serasi dalam keadilan. Lihat Soerjono Soekanto, Sosiologi Suatu Pengantar, Rajawali Press Jakarta, 1982, hlm. 94. 
disepaktinya sebuah perjanjian tertulis antara umat muslim dan non muslim yang dikenal dengan nama Piagam Madinah. ${ }^{10}$

Piagam Madinah merupakan undang - undang dasar tertulis pertama dalam Islam sekaligus sebagai kerangka dasar sebuah negara yang berdaulat. Di dalamnya tertanam prinsip Islam yang menyatakan bahwa umat Islam adalah bersaudara (al-muslimuna ikhwan) dan manusia berasal dari umat yang satu (ummatan wa hidatan). Dampak positif dari penanda tanganan Piagam Madinah tersebut ialah adanya pengakuan terhadap Nabi Muhammad saw sebagai kepala pemerintahan. Dengan demikian, nabi menyandang dua kekuasaan, yakni “ kekuasaan spritual " dan " kekuasaan duniawi ".11 Sejak saat itu,ia mulai berdakwah kepada masyarakat non muslim melalui pendekatan adopsi, akomodasi, dan seleksi. Secara teori, ketiga pendekatan ini tidak ditemukan dalam literatur dakwah. Akan tetapi, hal ini penulis nyatakan setelah melihat substansi materi dakwah Nabi Muhammad saw terhadap masyarakat non muslim di Madinah.

Indikasi ke arah ini terlihat dari beberapa materi dakwah Nabi Muhammad saw yang sangat adaptif, akomodatif, dan selektif. Contohnya dapat dilihat di dalam isi Piagam Madinah. Antara lain dicantumkan, bahwa masing-masing komponen Madinah mengakui adanya kesamaan derajat kemanusiaan yang harus dijunjung tinggi. Non muslim - terutama Yahudi harus mengakui keberadaan Islam sebagai sebuah agama yang diakui di Madinah. Demikian juga sebaliknya, umat Islam mengakui keyakinan Yahudi. ${ }^{12}$

Metode dakwah yang dikembangkan oleh Nabi Muhammad dalam periode ini pada akhirnya memberikan hasil yang gemilang. Islam yang terlihat adalah Islam yang rahmatan lil'alamin dan pembawa kabar gembira. Selain itu, usaha korespondensi dengan cara mengirimkan surat kepada raja-raja dan memperkenalkan dirinya sebagai Rasul dan

10 Piagam Madinah adalah sebuah perjanjian atau kesepakatan pertama yang terjadi dalam sejarah Islam antara masyarakat Islam dan non Islam. Lahirnya kesepakatan ini memberi dampak positif yang luar biasa dalam perkembangan dakwah Islam selanjutnya. Di dalamnya terdapat beberapa payung besar yang saling menghargai dan secara langsung memberi keuntungan penyebaran Islam di Madinah pada saat itu. Lihat, Philip K. Hitty. Op. Cit, hlm. 45 dan J. Suyuthi Pulungan, Op. Cit, hlm. 285 - 311. Salah satu isi perjanjian Madinah itu ialah : Orang Islam, Yahudi dan seluruh penduduk Madinah yang lain mereke menjamin keamanannya dalam menjalankan ibadah sesuai dengan keyakinan dan agamanya masing - masing. Tidak seorang pun dibenarkan mencampuri urusan agama orang lain.

11 Harun Nasution, Islam Ditinjau Dari Berbagai Aspeknya, Jilid I, UI Press, Jakarta, 1985, hlm. 101. Lihat juga Badri Yatim, Op.Cit, hlm. 25.

12 Ibnu Hisyam, Op.Cit, hlm. 504 
menjelaskan bahwa Islam adalah agama tauhid juga merupakan satu usaha penting dalam proses dakwahnya di Madinah. ${ }^{13}$

Keberhasilan dakwah yang diserukan oleh Nabi Muhammad saw mulai membuat kaum Kafir Quraisy meradang. Mereka menyatakan bahwa keberhasilan dakwah tersebut adalah hal yang harus dihentikan yang kemudian direalisasikan dengan melakukan kekejaman dan pemboikotan di bawah pimpinan Abdullah bin Ubay terhadap pengikut Nabi Muhammad saw. ${ }^{14}$ Menanggapi hal tersebut, nabi kemudian membentuk Tim Sembilan di bawah pimpinan Abdullah bin Jahsh, yang dipersiapkan untuk melindungi umat Islam. Kekejaman-kekejaman yang digencarkan oleh kaum Kafir Quraisy terhadap umat Islam dan pengikut nabi pada akhirnya mengakibatkan pecahnya peperangan yang terjadi antara dua kubu tersebut. ${ }^{15}$

Ada dua alasan mendasar Nabi Muhammad saw dan umat Islam melakukan pembelaan diri dengan perang. Pertama, untuk meyakinkan musuh-musuh Islam, bahwa Islam tidak lemah, dan kedua, sebagai bentuk peringatan kepada musuh-musuh Islam, bahwa umat Islam telah siap dan selalu waspada akan bahaya yang mengancam. ${ }^{16}$

Al-Quran menegaskan bahwa mempersiapkan diri dalam menghadapi musuh memang diperlukan. Allah Swt menjelaskan hal ini dalam surat al-Anfal (8) ayat 60 :

Artinya: Dan siapkanlah untuk menghadapi mereka kekuatan apa saja yang kamu sanggupi dan dari kuda-kuda yang ditambat untuk berperang (yang dengan persiapan itu) kamu menggentarkan musuh Allah dan musuhmu dan orang orang selain mereka yang kamu tidak mengetahuinya; sedang Allah mengetahuinya. apa saja yang kamu nafkahkan pada jalan Allah niscaya akan dibalasi dengan cukup kepadamu dan kamu tidak akan dianiaya (dirugikan). ${ }^{17}$

13 Surat-surat tersebut dikirim oleh Rasulallah kepada raja-raja yang ada di sekitar Madinah, seperti Najasi-Raja Habsyah, Mauquqis-Raja Mesir, Kisra-Raja Persia, Qaisar-Raja Romawi, Al-Mundzir bin Sawa, Haudzah bin Ali al-Hanafi-Pemimpin Yamamah, Al-Harits bin Abu Syamr al-Shassany-Pemimpin Damascus, dan Raja Oman. Melihat periode ini, Phillip K. Hitty menyatakan bahwa berangkat dari Madinah, Teokrasi Islam kemudian meluaskan pengaruhnya ke seluruh negeri Arab. Bahkan sebagian besar daerah Asia Barat dan Afrika Utara. Umat Islam Madinah merupakan contoh kecil umat Islam seluruhnya. Lihat Ibnu Hisyam, Op.Cit, hlm. 359-371., dan Philip K. Hitty,Op.Cit, hlm. 121

14 K. Ali, Sejarah Islam (Tarikh Pra Modern), PT. Raja Grafindo Persada, Jakarta, 2000, hlm. 48.

15 Ibid

16 Muhammad Al-Ghazali, Op Cit , hlm 364

${ }^{17} \mathrm{~A}$. Yusuf Ali, The Holy Qur'an Translation and Commentary, Islamic Propagation Centre International, 1946, hlm. 430. "The immediate occasion ofthis injuction was the weaknes of cavalary and appointments of war in the early fight of Islam. The are always lurking enemies whom you may not now, but whom god knows. Be always ready and put your all your resources 
Jika dianalisa, perjanjian dalam Piagam Madinah tersebut sebenarnya memuat dua unsur penting, yaitu agamis dan politis. Secara agamis, diterimanya perjanjian ini menunjukkan bahwa Islam adalah agama yang mengedepankan maaf dan perdamaian. Sedangkan secara politis, perjanjian ini mengikat kedua belah pihak untuk dapat menahan diri. Ada empat point penting yang disepakati dalam perjanjian tersebut. Salah satu diantaranya ialah pelaksanaan genjatan senjata antar dua kubu yang berseteru. ${ }^{18}$

Paparan latar belakang masalah diatas membuktikan bahwa Nabi Muhammad saw dengan menggunakan berbagai strategi dalam dakwahnya yang disesuaikan dengan kondisi dan keadaan mad'u yang ada, telah berhasil memberikan contoh dakwah yang sangat baik. Islam yang pada awalnya adalah agama yang asing dan tidak dikenal oleh masyarakat Madinah, akhirnya menjadi agama yang mereka bela dan yakini. Nabi sendiri tidak hanya berkedudukan sebagai penyampai agama saja, melainkan juga merangkap sebagai kepala pemerintahan. Keberhasilan dakwah nabi juga dapat dilihat dengan terwujudnya kehidupan yang aman berdampingan di kalangan masyarakat Madinah yang tetap heterogen dan plural.

Berdasarkan latar belakang yang telah dipaparkan, maka masalah pokok dalam penelitian ini adalah penganalisaan terhadap model dakwah Ukhuwah Basyariah dan Ukhuwah Wathaniyah yang ditinjau dari sejarah perjalanan dakwah Nabi Muhammad saw pada masyarakat Madinah, yang bertujuan untuk menganalisa model dakwah Ukhuwah Basyariah dan Ukhuwah Wathaniyah yang ditinjau dari sejarah perjalanan dakwah Nabi Muhammad saw pada masyarakat Madinah.

\section{PEMBAHASAN}

\section{A. Dakwah Melalui Ukhuwah Wathaniyah}

Dakwah melalui ukhuwah wathaniyah ialah menyampaikan Islam dengan menanamkan rasa cinta terhadap tanah air. Rasa mencintai dan memiliki (sense of belonging) tanah air merupakan hal yang penting untuk menciptakan suasana yang kondusif di suatu Negara. Dalam hal ini, Nabi Muhammad saw telah mencontohkan bahwa ajaran Islam tidak hanya

into your cause." Selantjutnya baca dan teliti al-Quran surat al-Hajj ayat 39 dan 41 . Dua ayat ini adalah penegasan Allah Swt yang mengizinkan umat Islam melakukan pembelaan dan memerangi orang yang memerangi Islam ('Telah diizinkan berperang terhadap orang yang memerangi, karena sesungguhnya mereka telah dianiyaya...dst)

18 Selanjutnya, isi lengkap dari Piagam Madinah dapat dilihat pada lampiran (bahagian akhir ) tulisan ini. 
berorientasi pada hal-hal ukhrawi, melainkan juga pada aspek duniawi. Sebagaimana yang terjadi pada masyarakat Madinah, Nabi Muhammad saw berhasil menyatukan mereka dalam ikatan persaudaraan, namun belum mencapai pada tingkatan sense of belonging tanah air (Madinah).

Ada beberapa alasan yang akhirnya menjadikan Nabi Muhammad saw memilih ukhuwah wathaniyah sebagai salah satu strategi dakwahnya di Madinah. Alasan pertama adalah terkait perbedaan rasa cinta dan memiliki Madinah yang terjadi di antara kaum Anshor dan Muhajirin. Kaum Anshor merupakan etnis asli yang berasal dari Madinah. Dengan demikian, sense of belonging kaum Anshor terhadap Madinah lebih besar dibandingkan dengan kaum Muhajirin yang berasal dari Makkah.

Alasan kedua, datang dari pihak eksternal muslim yang ada di Madinah, yaitu kaum Yahudi. Sebagai penduduk asli Madinah, kehadiran dan eksistensi Muslim di Madinah menyebabkan eksistensi kaum Yahudi dalam hal politik dan wilayah kekuasaan semakin menyempit dan terbatas. Alasan ketiga adalah dampak dari menyempitnya eksistensi kaum Yahudi. Mereka segera melakukan gerakan-gerakan guna menghalangi gerakan dakwah Nabi Muhammad saw di Madinah. Alasan kelima adalah bukti nyata dari gerakan yang dilancarkan oleh Yahudi untuk menghalangi dakwah nabi. Mereka membangkitkan semangat kesukuan (syu'ubiyah) di kalangan bangsa Arab Madinah yang bertujuan untuk memecah belah persatuan di antara umat Islam di Madinah. Dalam hal ini mereka menggunakan isu-isu permusuhan antara kaum Anshor dan Muhajirin yang sebenarnya telah mampu diredam oleh nabi. Alasan kelima adalah ancaman dan serangan yang berasal dari kaum Kafir Quraisy yang ada di Mekkah. Mereka mengganggu umat Islam di Mekkah untuk mengganggu ketenangan umat Islam di Madinah yang akhirnya akan berimbas pada terganggunya kestabilitasan kota Madinah. ${ }^{19}$

Menghadapi realita seperti itu, Nabi Muhammad saw merespon dengan menyusun langkah-langkah strategis untuk memupuk ukhuwah wathaniyah masyarakat Islam di Madinah. adapun langkah-langkah yang dilakukan ialah: 1) Memberika penjelasan tentang pentingnya cinta tanah air. 2) Melakukan latihan ketangkasan dan bela diri. 3) Memanah dan mengunggang kuda. 4) Melakukan berbagai ekspedisi. ${ }^{20}$

Segala usaha yang dicanangkan oleh Nabi Muhammad saw untuk menghadapi serangan kaum Kafir Quraisy tersebut sudah ditetapkan oleh Allah melalui firmannya. Ada beberapa surah dalam alQuran yang membahas tentang hal tersebut, di antaranya:

1. Al-Quran pada surat al-Anfal (8) ayat 59.

\footnotetext{
${ }^{19} \mathrm{Al}$ Ghazali, Op. Cit, hlm, 207

${ }_{20}$ Ibid
} 
Artinya : Dan janganlah orang-orang yang kafir itu mengira, bahwa mereka akan dapat lolos (dari kekuasaan Allah). Sesungguhnya mereka tidak dapat melemahkan (Allah).

2. Al-Quran surat An-Nisa ayat 84, yang berkaitan dengan seruan untuk berjihad dan berinfaq.

Artinya : Maka berperanglah kamu pada jalan Allah, tidaklah kamu dibebani melainkan dengan kewajiban kamu sendiri. Kobarkanlah semangat para mukmin (untuk berperang). Mudah-mudahan Allah menolak serangan orang-orang yang kafir itu. Allah amat besar kekuatan dan amat keras siksaan-Nya.

Semangat untuk memberikan perlawanan terhadap kaum Kafir Quraisy tersebut juga mengharuskan nabi melatih semangat dan melakukan latihan militer terhadap umat Islam. Latihan-latihan militer ini dirasa perlu untuk mengasah kekuatan kaum muslimin demi melindungi saudara semuslim dan tanah air mereka, yang nantinya akan menimbulkan rasa cinta terhadap tanah air. ${ }^{21}$

Sebagi tindak lanjut dari pelatihan militer yang diprakarsai Nabi Muhammad saw tersebut, nabi memerintahkan umat Islam melakukan beberapa kali ekspedisi, sebagai berikut :

1. Pada bulan Ramadhan tahun pertama hijrah. Hamzah bin Abdul Muthalib memimpin pasukan yang berkekuatan tiga puluh orang berpapasan dengan rombongan Quraisy yang dipimpin Abu Jahal dengan kekuatan tiga ratus iring-iringan unta. Pada saat ini tidak terjadi pertumpahan darah, karena dicegah oleh Majid bin Umar al-Jahni.

2. Pada bulan Syawal tahun yang sama. 'Ubaidah bin Al-Haris dengan membawa enam puluh orang pasukan ke lembah Rabigh. Disini mereka berpapasan dengan rombongan yang dipimpin oleh Abu Sofyan dengan kekuatan dua ratus orang. Saat itu kedua belah pihak melepas anak panah, tetapi tidak sampai pada peperangan yang menelan korban.

3. Pada bulan Dzulqa'edah. Sa'ad bin Abi Waqash keluar membawa kekuatan dua puluh orang pasukan untuk menghalangi pasukan kafir Quraisy.

4. Pada bulan Safar tahun kedua Hijrah, setelah Nabi Muhammad saw mewakilkan urusan Madinah kepada Sa'ad bin Ubadah, nabi memimpin langsung sebuah pasukan untuk menghalangi rombongan orang-orang Bani Dhimrah di Waddan. Tidak terjadi peperangan, dan nabi mengadakan perjanjian dengan Bani Dhamrah.

21 Ibid, hlm. 210 
5. Pada bulan Rabiul Awal tahun yang sama Nabi Muhammad saw bersama kaum Anshor dan Muhajirin dengan kekuatan dua ratus orang mencegah orang-orang kafir di Buwath di bawah pimpinan Umayyah bin Khalaf.

6. Pada bulan Jumadil Awal Nabi Muhammad saw keluar menuju 'Asyirah, tempat kabilah terkuat di Yanbu'. Disana beliau tinggal selama sebulan dan melakukan perjanjian perdamaian dengan kabilah Bani Mundij.

7. Beberapa waktu kemudian, Karz bin Jabir Al-Fihri menggempur pinggiran Madinah dan merampok ternak penduduk. Nabi langsung memimpin pasukan perlawanan dan mengejar musuh hingga ke lembah Shafwan dekat Badar. Sesampainya disana nabi tidak bertemu dengan musuh, peristiwa ini merupakan cikal bakal dan pemicu pecahnya perang Badar. ${ }^{22}$

Jika dilihat dari penjabaran di atas, maka akan terlihat bahwa Nabi dan kaum muslimin sengaja melakukan hal-hal yang memicu peperangan dengan kaun Quraisy. Namun tidak demikian. Latihan militer dan ekspedisi tersebut dilakukan semata-mata untuk membentuk rasa kecintaan muslim terhadap tanah air mereka, dan juga sebagai usaha untuk melindungi saudara, dan agama serta keyakinan mereka. Ekspedisi-ekspedisi yang mereka lakukan bukanlah bertujuan untuk meluaskan wilayah kekuasaan Islam. Ekspedisi dan latihan militer tersebut juga ditunjang dengan semangat-semangat dakwah yang digemparkan oleh nabi melalui khutbah-khutbanhnya. Ia sering menyampaikan bahwa Bumi dan segala isinya juga ciptaan Allah Swt. Oleh karena itu Madinah adalah milik kita bersama. Kita wajib menjaganya dengan menjahui permusuhan. ${ }^{23}$ Strategi tersebut ternyata berhasil menumbuhkan kesadaran di kalangan masyarakat muslim di Madinah. mereka juga bertekad untuk membantu merealisasikan cita-cita dari Nabi Muhammad saw tersebut. Dengan demikian, mereka semakin rajin untuk berinfaw, berjihad, serta tidak berhitung dalam membela agama Islam. Selain itu, mereka juga bersifat lebih toleran dan tidak membalas setiap kejahatan kaum Yahudi yang ada di Madinah. ${ }^{24}$

Seorang sejarawan Islam, Muhammad Al-Ghazaly menyatakan, bahwa ada dua alasan mendasar sehingga umat Islam dibolehkan berperang. Pertama, untuk menanamkan kesan dikalangan kaum musyrikin, Yahudi, dan Arab Badui (yang berkeliaran di Madinah pada waktu itu), bahwa orang Islam telah kuat dan tetap bersatu membelah tanah air dan keyakinannya. Kedua, gerakan militer tersebut sebagai

\footnotetext{
22 Ibid, hlm. 212-213

23 Ibnu Hisyam, Op. Cit, hlm. 496 dan 501-502.

24 Al-Ghazaliy, Op. Cit, hlm. 199-203
} 
peringatan atas sikap orang kafir yang selalu mengintimidasi umat Islam. ${ }^{25}$

Pada perkembangannya, kehadiran Nabi Muhammad saw dan para pengikutnya yang dinilai ramah dan membawa kedamaian, menjadikan kaum Yahudi akhirnya mengajukan perdamaian. Perdamaian tersebut terwujud dalam sebuah kesepakatan tertulis yang kemudian disebut dengan Piagam Madinah. Tidak ditemukan data yang pasti terkait waktu, tanggal, serta hari dimana perjanjian ini disahkan. Meskipun demikian, Piagam Madinah merupakan sebuah perjanjian tertulis monumental dalam perjalanan sejarah Islam. Di dalamnya terdapat sebuah payung besar yang mewadahi kehidupan umat Islam dan non muslim di Madinah. Dengan bahasa lain, kehadiran Piagam Madinah ini merupakan sebuah bentuk reformasi total bagi masyarakat Madinah. Salah satu isinya yang sangat strategis ialah : Orang Islam, Yahudi dan seluruh penduduk Madinah yang lain bebas memeluk agama dan kepercayaannya masing - masing. Mereka dijamin keamanannya dalam menjalankan ibadah sesuai dengan keyakinannya dan agamanya masing - masing. Tidak seorangpun dibenarkan mancampuri urusan agama orang lain. $^{26}$

Dalam aspek politik, dampak terbesar dari disahkannya Piagam Madinah bagi keberadaan Nabi Muhammad saw dan para pengikutnya adalah diterimanya nabi di Madinah dan juga diangkatnya nabi menjadi Hakam, atau kepada pemerintahan. Dengan demikian, sejaka saat itu, Madinah telah resmi dipimpin langsung oleh Nabi Muhammad saw. ${ }^{27}$ Pada butiran lain juga dinyatakan bahwa penduduk Madinah adalah umat yang satu dan mendiami satu wilayah - yaitu Madinah. Disana juga diatur cara hidup dalam bernegara dan bermasyarakat. ${ }^{28}$.

Meskipun terdapat perbedaan pendapat terkait keberadaan Nabi Muhammad saw sebagai kepala pemerintah, penanda tanganan Piagam Madinah tersebut telah membuka jalan bagi Islam untuk terus meluaskan pengaruhnya. Hal ini dikarenakan pada diri Rasul Saw terdapat dua kekuasaan, yaitu kekuasaan spritual dan kekuasaan duniawi. ${ }^{29}$ Umat Islam, terutama kaum Muhajirin tidak lagi merasa asing di Madinah, sebaliknya mereka merasa Madinah adalah tanah kelahiran mereka yang harus

25 Ibid, hlm. 214

26 Lihat philip K. Hitty, Op. Cit. hlm. 45. Ibnu Hisyam, Op. Cit, hlm. 501-502.

27 Montogomery Watt,Muhammad Prophet and Statement, Oxford University Press, 1969, hlm. 222-223. Akan tetapi bila di simak kitab suci Al-Quran, maka tidak ditemukan satu ayatpun yang mengatakan Rasul Saw adalah kepala pemerintahan selama di Madinah. Beliau adalah seorang Rasul Saw yang bertugas menyampaikan ajaran Islam.

28 Ibnu Hisyam, Ibid. Naskah lengkap Piagam Madinah ini akan dilampirkan pada bagian akhir buku ini.

${ }^{29}$ Harun Nasution, Islam Ditinjau dari Berbagai Aspeknya, Jilid I, Op. Cit., hlm. 101. 
mereka bela. Sikap ini kemudian berdampak luas kepada masyarakat lainnya dan memunculkan sikap kesadaran untuk membela dan melindungi Madinah dari serangan musuh. ${ }^{30}$

Secara sosiologi, strategis dakwah yang dikembangkan oleh Nabi Muhammad saw ini pada gilirannya berhasil membawa perubahan pada masyarakat Madinah. Masyarakat Madinah yang sebelumnya merupakan masyarakat yang tidak berstruktur, nomaden, kemudian berubah menjadi sebuah masyarakat kota yang berperadaban menurut ukuran pada waktu itu. ${ }^{31}$ Perubahan tatanan sebuah masyarakat memang dapat disebabkan oleh fungsionalisasi agama itu sendiri. Nottingham menjelaskan, bahwa agama membantu masyarakat mendorong terciptanya kondisi sosial yang berkewajiban. Setiap anggota masyarakat dapat menyalurkan fungsi dan nilai-nilai kemasyarakatan menuju sistem sosial yang utuh dan terpadu. ${ }^{32}$

Secara sederhana, strategi dakwah yang digagas oleh Nabi Muhammad saw melalui ukhuwah wathaniyah ini telah membuahkan hasil, walaupun belum mencapai tingkat kemaksimalan secara menyeluruh, namun indikasi yang mengarah kepada keberhasilan ini dapat dilihat ketika mereka memperhatikan tanggung jawab yang sama terhadap Madinah. Orang-orang Muhajirin telah merasa Madinah adalah bagian dari diri mereka sendiri. Ira M.Lapidus ${ }^{33}$ menerangkan, bahwa dari sana Nabi Muhammad saw dan pengikutnya kaum Muhajirin membentuk sebuah kelompok politik bersama dengan clan yang ada di Madinah, yang disebut ummah. Ummah adalah istilah yang diperuntuhkan bagi komunitas Muslim. Muslim Makkah dan seluruh warga Madinah harus mempertahankan Nabi Muhammad saw dan Madinah dari serangan pihak luar, dan tidak satupun clan Madinah diperbolehkan membentuk pertahanan secara terpisah.

\section{B. Dakwah Melalui Ukhuwah Basyariah}

Aktifitas dakwah Nabi Muhammad saw di Madinah terus mengarah kepada perkembangan dakwah yang signifikan serta menampakkan sinyal-sinyal keberhasilan, khususnya pasca penanda tanganan Piagam Madinah. Secara internal, kerukunan umat Islam dan kecintaan mereka terhadap Madinah telah muncul. Akan tetapi,

${ }^{30}$ Haikal,Op. Cit, hlm. 199-205

31 Nurcholis Madjid, Islam, Agama,Dan Peradaban, Yayasan Paramadina, 1996, hlm. 23. dan Soerjono Soekanto, Sosiologi Suatu Pengantar, Op. Cit., hlm. 166-170.

32 Elizabeth K. Nottingham, Religion and Society, (terj.). Abdul Muis Naharong, Agama Dan Masyarakat, Suatu Pengantar Sosiologi Agama, PT. Raja Grafindo Persada, Jakarta, 1996. hlm.36

33 Ira M. Lapidus, A. History od Islamic Societies, Cambridge University Press, Australia, 1993, hlm. 27. 
terkadang mereka merasakan sikap syu'ubiyah atau fanatik kesukuan itu muncul kembali. Hal tersebut mengisyaratkan bahwa mereka masih memerlukan persaudaraan atas dasar kemanusiaan (ukhuwah basyariah). ${ }^{34}$ Karena apabila kondisi ini dibiarkan, maka akan membuka peluang kepada mereka untuk saling mencari kelemahan. ${ }^{35}$

Melihat realita dan perkembangan yang terjadi di kalangan masyarakat Madinah, Nabi Muhammad saw menyusun strategi selanjutnya, yaitu melahirkan sikap kebersamaan. Nabi ingin menanamkan sebuah keyakinan, bahwa semua manusia itu adalah sama. Sama- sama makhluk Allah Swt yang berasal dari satu nenek moyang, yaitu Adam as dan Hawa. Dengan demikian, nabi ingin mengikat mereka dengan tali persudaraan atas dasar nilai kemanusiaan. Sebuah persaudaraan yang diikat atas dasar kesamaan ciptaan, yaitu manusia sebagai ciptaan Allah Swt.

Landasan strategi dan materi dakwah ini sesuai dengan ajaran Islam sebagaimana tercantum dalam surat Al-Hujarat ayat 13 :

Artinya: Hai manusia, Sesungguhnya kami menciptakan kamu dari seorang laki-laki dan seorang perempuan dan menjadikan kamu berbangsa - bangsa dan bersuku-suku supaya kamu saling kenal-mengenal. Sesungguhnya orang yang paling mulia diantara kamu disisi Allah ialah orang yang paling taqwa diantara kamu. Sesungguhnya Allah Maha mengetahui lagi Maha Mengenal.

Ayat ini menjelaskan, bahwa Allah Swt memang menciptakan manusia dalam keadaan yang berbeda, baik suku, bangsa, budaya, adat istiadat, bahkan agama. Akan tetapi Allah Swt tidak bermaksud menjadikan perbedaan tersebut sebagai penyebab timbulnya pertikaian apalagi permusuhan. Sebaliknya Allah Swt menciptakan hamba-NYA berbeda, supaya mereka saling mengenal, menyayangi, dan mencintai.

Walaupun bangsa Arab adalah bangsa yang sangat menghargai garis keturunan dan mengenal berbagai strata. ${ }^{36}$ Akan tetapi, secara hakikat penciptaan manusia itu sama seluruhnya. Tidak ada perbedaan satu bangsa dengan bangsa lain, tidak juga dikarenakan suku, ras, dan warna kulit. Sebagaimana yang disabdakan oleh Nabi Muhammad saw.

${ }^{34}$ Kata Basyariyah yang berakar dari Basyar diulang sebanyak 26 kali dalam AlQuran. Kata ini berarti manusia. Oleh karena itu, penulis mengartikan ukhuwah basyariyah adalah persaudaraan yang dibina atas dasar kemanusiaan.Lihat Al-Baqi, Op.Cit, hlm. 153.

35 Ibid

${ }^{36}$ Ahmad Musthafa Al-Maraghi, Tafsir al-Maraghi. Jilid 9, Dar al-Kitan al-Ilmiyah, Beirut, 1998, hlm. 254-256. Lebih jauh diterangkan al-Maraghi, bahwa bangsa Arab mengenal tujuh tingkatan keturunan, yaitu : sya'ab, kabilah, imarah, bath, fakhz, fashilah dan 'asyirah. 


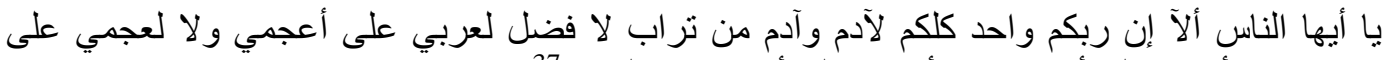

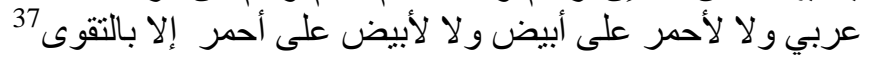
Artinya: Wahai manusia, Tuhan kamu adalah Tuhan yang Esa, Ayah kamu satu berasal dari Adam dan Hawa yang berasal dari tanah. Tidak ada keutamaan orang Arab dengan yang bukan Arab, orang berkulit merah dan hitam, kecuali karena taqwanya.
\end{abstract}

Dalam kajian dakwah, menempatkan manusia pada derajat yang sama merupakan sebuah kemestian. Yang dimaksud "sama" dalam hal ini ialah sama-sama makhluk Allah Swt yang secara fitrah adalah makhluk beragama. Selain itu, manusia juga merupakan makhluk sosial yang mencintai kebersamaan dan membenci pertikaian apalagi permusuhan. Para sosiolog -seumpama Soerjono Soekanto- memang menegaskan bahwa strata kehidupan dalam masyarakat akan menimbulkan rasa persaingan (competition) dan perjuangan untuk bertahan (struggle for exsistence). Keduanya merupakan konsepsi-konsepsi dasar dalam pendekatan ekologis. ${ }^{38}$

Selain sebagai makhluk sosial, manusia juga merupakan makhluk yang berketuhanan. Secara fitrah setiap manusia membutuhkan agama sebagai pengatur hidupnya. Oleh karena itu, Nabi Muhammad saw memfungsikan agama sebagai wadah pemersatu. ia memperlihatkan hubungan yang jelas antara agama dan persamaan derajat. Agama merupakan fasilitator dan dinamisator yang menjembatani perbedaan.

Agama juga sangat berperan besar dalam menentukan sisi kehidupan manusia. Ajaran agama merupakan payung besar dalam membingkai kebersamaan. Karena, pada setiap diri manusia ada naluri atau fitrah untuk beragama. Ini adalah modal besar Nabi Muhammad saw dalam mewujudkan ukhuwah basyariah di tengah keragaman masyarakat Madinah.

Agama sebagai sebuah sistem nilai dapat menjadi bagian yang tidak terpisahkan dengan nilai yang ada di masyarakat. Agama mampu menjadi pendorong dan penggerak sekaligus pengontrol gerak masyarakat. Secara sosiologi, kebutuhan akan agama bersentuhan langsung dengan dinamika masyarakat itu sendiri. Di masyarakat akan terlihat beberapa simbol keagamaan sebagai pengikat. Oleh karena itu, memfungsikan agama sebagai roda persatuan merupakan sesuatu kemestian. ${ }^{39}$

37 Imam Ahmad Bin Hambal, Al-Musnad, Jilid IV, Dar Al-Kutub al-Iliyah, Beirut, 1993, hlm. 496.

${ }^{38}$ Soerjono Soekanto, Beberapa teori Sosiologi Tentang Struktur Masyarakat, PT. Raja Grafindo Persada, Jakarta, 1993, hlm. 69.

39 Hendro Puspito, Sosiologi Agama, Kanisius, Jakarta, 1992, hlm. 38. 
Apabila dihubungkan fungsionalisasi agama dengan salah satu isi Piagam Madinah khususnya tentang prinsip persamaan, akan terlihat sebuah hubungan yang simbiotis. Titik sentuh keduanya terletak pada upaya mempersamakan manusia. Walaupun manusia berbeda dari jenis kelamin, warna kulit, sifat, bakat, kekuasaan, agama hingga strata sosial, sesungguhnya manusia itu adalah sama. Masyarakat Madinah adalah umat yang satu dan mempunyai status yang sama dalam kehidupan sosial (lihat pasal 25-35).

Sisi lain dari bentuk ukhuwah basyariah ini, ialah munculnya sebuah realitas kebebasan yang saling menghormati. Jika ukhuwah Islamiyah menumbuhkan kerukunan antar penganut Islam secara internal, maka ukhuwah basyariah menumbuhkan kerukunan antar umat sesama pemeluk agama. Masyarakat Madinah memiliki kebebasan untuk memilih agama yang diyakininya, tetapi harus saling menghormati agama dan kepercayaan orang lain. Dalam pasal 25 Piagam Madinah menyatakan, bahwa orang Yahudi tetap berpegang pada agama mereka begitu pula orang Islam. Fazlur Rahman mengomentari pasal ini sebagai bentuk kebebasan beragama dan berintegrasi sesama manusia sebagai pemeluk agama yang berbeda. ${ }^{40}$

Adanya kebebasan dan jaminan memilih agama dan keyakinan bagi masyarakat Madinah, pada hakikatnya tidak mengurangi esensi dakwah itu sendiri. Karena prinsip dakwah Islam adalah mengajak dan menyampaikan kebenaran. Dakwah Islam tidak pernah memaksa mad'unya untuk memilih Islam secara mutlak. Jika Allah Swt berkehendak sesama manusia beriman, maka hal itu sangat mudah bagi-Nya. Dengan demikian seorang $d a^{\prime} i$ tidak dibenarkan memaksa audiennya untuk mengimani agama yang didakwahkannya. 99

Hal ini ditegaskan Allah Swt dalam al-Quran surat Yunus (10) ayat

Artinya : Dan Jikalau Tuhanmu menghendaki, tentulah beriman semua orang yang di muka bumi seluruhnya. Maka apakah kamu (hendak) memaksa manusia supaya mereka menjadi orang-orang yang beriman semuanya?

Ayat Al-Quran ini merupakan bukti kuat bahwa manusia mempunyai kebebasan untuk memilih agama yang diyakininya. Artinya bahwa, Islam menghargai adanya toleransi terhadap umat untuk memilih agama. Prinsip kebebasan yang tercantum di dalam Piagam Madinah ini merpakan babak baru dalam kehidupan masyarakat saat itu. ${ }^{41}$ Dengan

13.

40 Fazlur Rahman, Islam, (terj.) Ahsin Muhammad, Mizan, Bandung, 1984, hlm.

${ }^{41}$ Haikal, Op. Cit, hlm. 205 
demikian upaya Nabi Muhammad saw dalam menciptakan persaudaraan sesama manusia mendapat dukungan dan legitimasi dari Allah Swt. Persatuan dan persaudaraan dalam Islam merupakan dasar utama akan terbentuknya sebuah tatanan masyarakat yang berperadaban. Secara inflisit tatanan ini menunjukkan adanya keutuhan yang harus dipelihara oleh setiap manusia sebagai makhluk sosial. Bila diamati strategi dakwah Nabi Muhammad saw melalui ukhuwah basyariah ini, sesungguhnya ia telah melakukan sebuah perubahan besar. Perubahan besar ini ditandai dari segi materinya secara umum. Selain itu ia juga telah memberikan warna atau "corak baru" bagi masyarakat Madinah. ${ }^{42}$ Sisi lain yang dilahirkan ukhuwah basyariah, ialah terlihatnya nuansa kebersamaan. Kebersamaan dalam hak dan kedudukan sebagai anggota masyarakat.

Apabila dilakukan sebuah analisa, maka keberhasilan strategi diatas disebabkan oleh beberapa faktor :

1. Terbinanya persatuan umat Islam secara internal walaupun mereka berbeda suku, bangsa, dan adat kebiasaan serta tempat tinggal. Umat Islam adalah umatan wahidatan (Q.S / 4:1).

2. Keberadaan Islam sebagai agama yang menjunjung nilai kemanusiaan. Agama Islam tidak dikhususkan kepada satu kelompok saja, akan tetapi Islam adalah agama rahmatan lil'alamin (Q.S / 27:107).

3. Keterbukaan dan kesediaan masyarakat Madinah menerima kehadiran Nabi Muhammad saw.

4. Nabi Muhammad saw menampakkkan Islam sebagai agama yang menjunjung tinggi nilai kebersamaan dan pembawa kabar gembira (Q.S / 34:28).

5. Kemampuan Nabi Muhammad saw merebut hati dan meyakinkan masyarakat Madinah.

6. Ketepatan Nabi Muhammad saw dalam penggunaan strategi dakwah.

7. Adanya rekonsialiasi, secara politik upaya ini dapat disebut sebagai rekonsiliasi maksimal. ${ }^{43}$

8. Mengenalkan Islam melalui budaya masyarakat. Secara antropologi agama, type masyarakat pada waktu itu sulit

\footnotetext{
${ }^{42}$ Yang dimaksud dengan corak baru ialah, terdapatnya sebuah persatuan dan peradaban yang secara administrasi dan hukum akan merupakan cikal bakal sistem pemerintahan. Sebelum kehadiran Rasul Saw mereka masih terpisah dalam satu kesatuan kabilah yang sulit untuk dipertemukan. Keterangan selanjutnya lihat Thomas W. Arnold, The Spread of Islam In The World A History Of Peaceful Preacheng Goodword Books Pvt. Ltd , India, 2003 ,hlm. 31-32.

${ }^{43}$ Afzal Iqbal, Diplomacy in Early Islam, (terj.) Samson Rahman, Diplomasi Islam, Pustaka Al-Kautsar, Jakarta, 2000, hlm. 11.
} 
untuk menjalin sebuah kerjasama dalam bentuk apapun apalagi menerima sebuah ajaran baru. Akan tetapi, melalui pendekatan budaya setempat dengan jembatan ukhuwah tersebut, Islam mereka terima dan melahirkan semangat kerja sama sebagai makhluk berketuhanan dan sosial. ${ }^{4}$

Faktor-faktor diatas menunjukkan bahwa Nabi Muhammad saw melaksanakan dakwahnya secara terencana, sistematis, dan menggunakan strategi yang tepat. Dalam perencanaannya, ia memperhatikan aspek sosiologi dan antropologi yang ada pada masyarakat tersebut. Kesistematisannya terlihat dari caranya memisahkan antara satu kelompok dengan kelompok lain, sehingga materinya tidak berhimpit. Sedangkan kestrategiannya ialah ketika ia memperkokoh Islam secara internal dan ekternal. Sisi lain yang perlu mendapat perhatian dari praktek dakwah ini ialah menyatunya $d a^{\prime} i$ dan mad' $^{\prime} u$.

Keberhasilan dakwah Nabi Muhammad saw ini merupakan teladan dalam sejarah dakwah dan kemanusiaan. Ia telah berhasil membangun sebuah masyarakat yang sangat heterogen dan berpotensi konflik menjadi masyarakat yang bertatanan dan berperadaban. Hal ini merupakan langkah awal yang baik sebelum ia melangkah ke wilayah yang lebih luas dan sangat spesifik, yaitu masyarakat non muslim di Madinah.

\section{Kesimpulan}

Berdasarkan penjabaran pembahasan di atas, maka dapat ditarik beberapa kesimpulan, sebagai berikut:

1. bahwa perjalanan dakwah Nabi Muhammad selama 23 tahun terbagi ke dalam dua periode, yaitu 13 tahun di Makkah dan 10 tahun di Madinah.

2. periode dakwah Nabi Muhammad saw selama di Makkah terbagi ke dalam tiga fase, yaitu dakwah secara sembunyi-sembunyi, dakwah secara terang-terangan, dan dakwah keluar Makkah yang nantinya akan berlanjut di Madinah.

3. berbeda dengan proses dakwah yang dilalui oleh Nabi Muhammad saw selama di Makkah. Dakwah di Madinah selama 10 tahun yang dimulai sejak tahun pertama nabi hijrah ke Madinah sebenarnya mendapat tantangan yang lebih besar. Jika di Makkah nabi

${ }^{44}$ Hilman Hadikusuma, Antropologi Agama II (Pendekatan Budaya Terhadap Agama Yahudi, Kristen Katolik, Protestan dan Islam), Citra Aditiya, Bandung, 1993, hlm 176. 
menghadapi masyarakat yang homogen, maka di Madinah nabi dihadapkan pada masyarakat yang heterogen.

4. Periode dakwah yang dilakukan oleh nabi selama di Madinah mengarah kepada keberhasilan dakwah. Hal ini diperkuat pasca diresmikannya Piagam Madinah oleh nabi dan penduduk Madinah. Selain itu, keberhasilan Nabi Muhammad saw dalam menetralisir pertikaian yang sering terjadi di kalangan masyarakat Madinah, khususnya kaum Muhajirin dan Anshor juga merupakan bukti nyata keberhasilan dakwah Nabi Muhammad saw selama di Madinah. Dalam proses dakwah di Madinah, nabi juga mencanangkan dua strategi, yaitu menanamkan Ukhuwah Wathaniyah dan Ukhuwah Basyariah.

5. Ukhuwah Wathaniyah merupakan usaha untuk menumbuhkan sikap cinta terhadap tanah air, dalam hal ini adalah Madinah. Dengan menggunakan strategi ini, nabi berusaha untuk menyatukan umat Islam di Madinah dan menumbuhkan rasa cinta dan memiliki tanah air di kalangan umat Islam. Ukhuwah Wathaniyah ini juga diasah dengan melakukan ekspedisi-ekpsedisi terhadap orangorang yang menentang Islam. Latihan militer dan ekspedisi tersebut digencarkan sebagai sebuah pembuktian bahwa umat Islam adalah umat yang kuat.

6. Ukhuwah Basyariah merupakan semangat persaudaraan atas dasar kemanusiaan. Strategi ini digencarkan oleh Nabi Muhammad saw dengan menanamkan keyakinan di kalangan umat Islam bahwa seluruh umat Islam adalah sama di hadapan Allah Swt, sekalipun mereka berasal dari etis, agama, budaya, dan bangsa yang berbeda. Hal ini kemudian berakibat pada sikap toleransi yang terwujud di kalangan masyarakat Madinah, baik Islam maupun non Islam. Strategi dakwah ini pula yang nantinya akan menjadi jalan pembuka bagi dakwah Nabi Muhammad saw kepada umat non Islam di Madinah.

\section{Referensi}

Al-Ghurraby, Ali Mushtofa. Tarikh al Firaq al Islamiyah Wa Nasy'atu al 'ilm al Kalam 'Inda al Muslimin. Kairo: Maktabah Wa Matba'ah, t.t.

Ali, A. Yusuf. The Holy Qur'an Translation and Commentary, Islamic Propagation Centre International, 1946, 
Ali, K. Sejarah Islam (Tarikh Pra Modern). Jakarta: PT. Raja Grafindo Persada, 2000.

Al-Maraghi, Ahmad Musthafa. Tafsir al-Maraghi. Jilid 9. Beirut: Dar alKitan al-Ilmiyah, 1998.

Al-Mubarakfury, Shafiyur Rahman. Sirah Rasul Saw al-Rahiqul Makhtum. Cet. II. Beirut: Dar al-Khair, 1998.

Arnold, Thomas W. The Spread of Islam In The World A History Of Peaceful Preacheng. India: Goodword Books Pvt. Ltd, 2003.

Bin Hambal, Imam Ahmad. Al-Musnad, Jilid IV, Beirut: Dar Al-Kutub alIliyah 1993.

Hadikusuma, Hilman. Antropologi Agama II (Pendekatan Budaya Terhadap Agama Yahudi, Kristen Katolik,Protestan dan Islam). Bandung: Citra Aditiya, 1993.

Haikal, Muhammad Husein. The Life of Muhammad. New Delhi: Cresent Publishing, 1976.

Hitti, Philip K. History of The Arabs. London: Mac Millan Press, 1970.

Iqbal, Afzal. Diplomacy in Early Islam, (terj.) Samson Rahman, Diplomasi Islam. Jakarta: Pustaka Al-Kautsar, 2000.

Lapidus, Ira M. Lapidus. A. History od Islamic Societies. Australia: Cambridge University Press, 1993.

Lewis, Bernard. The Arabs in History, (Terj.) Drs. Said Jamhuri, BangsaBangsa Arab Dalam Lintasan Sejarah. Jakarta: Pedoman Ilmu Jaya, 1988.

Madjid, Nurcholis. Islam, Agama,Dan Peradaban. Yayasan Paramadina, 1996.

Nasution, Harun. Islam Ditinjau Dari Berbagai Aspeknya, Jilid I. Jakarta: UI Press, 1985

Nottingham, Elizabeth K. Religion and Society, (terj.). Abdul Muis Naharong, Agama Dan Masyarakat, Suatu Pengantar Sosiologi Agama. Jakarta: PT. Raja Grafindo Persada, 1996. 
Pulungan, J. Suyuthi. Prinsip-Prinsip Pemerintahan Dalam Piagam Madinah Ditinjau Dari Pandangan al-Qur'an. Jakarta: Rajawali Pers, 1994.

Puspito, Hendro Puspito. Sosiologi Agama. Jakarta: Kanisius, 1992.

Rahman, Fazlur Rahman. Islam, (terj.) Ahsin Muhammad. Bandung: Mizan, 1984.

Seokanto, Soerjono. Sosiologi Suatu Pengantar. Jakarta: Rajawali Press, 1982. . Beberapa teori Sosiologi Tentang Struktur Masyarakat. Jakarta: PT. Raja Grafindo Persada, 1993. . Sosiologi Suatu Pengantar. Jakarta: Rajawali Press, 1990.

Watt, Montogomery. Muhammad Prophet and Statement. London: Oxford University Press, 1969. . Muhammad And Statetmen. London: Oxford University, 1979.

Yatim, Badri. Sejarah Peradaban Islam. Jakarta: PT. Raja Grafindo Persada, 2000. 